\title{
Penggunaan Steroid dalam Tata Laksana Sepsis Analisis Kasus Berbasis Bukti
}

\author{
Ariani Dewi Widodo, Alan Roland Tumbelaka
}

Departemen Ilmu Kesehatan Anak, RS Dr Cipto Mangunkusumo, Fakultas Kedokteran Universitas Indonesia, Jakarta

\begin{abstract}
Sepsis merupakan salah satu penyebab kematian terbanyak di rumah sakit dengan mortalitas 50\%-60\%, meskipun dengan terapi antibiotik dan tata laksana suportif yang adekuat. Steroid merupakan pilihan terapi pada sepsis yang masih kontroversial sejak empatpuluh tahun yang lalu. Muncul pertanyaan klinis, apakah pemberian steroid memberikan respon terapi lebih baik dan meningkatkan kesintasan pada sepsis dibandingkan terapi konvensional? Ilustrasi kasus dan penelusuran kepustakaan menggunakan instrumen pencari Pubmed, Highwire, dan Cochrane Library sesuai kata kunci.

Pada penelusuran didapatkan 16 artikel yang relevan 4 telaah sistematik, 9 uji klinis acak terkontrol, 1 kohort, dan 2 review. Levels of evidence ditentukan berdasarkan klasifikasi Oxford atau Methodologic Quality Form dari Cronin. Kortikosteroid dosis rendah jangka panjang sebaiknya diberikan pada semua syok septik dependen vasopresor. Kortikosteroid tidak dianjurkan pada sepsis tanpa syok. Kortikosteroid dosis tinggi dapat membahayakan pada sepsis berat dan syok septik. Steroid diberikan berdasarkan keputusan klinis, bukan hasil laboratorium maupun protokol. Kortikosteroid memperbaiki keadaan syok septik persisten dan lebih cepat memulihkan gangguan hemodinamik, sehingga menurunkan mortalitas. (Sari Pediatri 2010;11(6):387-94).
\end{abstract}

Kata kunci: sepsis, syok septik, kortikosteroid, kesintasan

Alamat korespondensi:

Dr. Alan Roland Tumbelaka Sp.A(K) Divisi Infeksi dan Pediatri Tropis, Departemen Ilmu Kesehatan Anak FKUI-RSCM Jl. Salemba no. 6, Jakarta 10430. Telepon: 021-3914126. Fax.021-390 7743 mengalami syok septik.2 Secara umum mortalitas di rumah sakit $30 \%$ pada sepsis berat dan 50\%$60 \%$ untuk syok septik. ${ }^{1,2}$ Departemen Ilmu Kesehatan Anak Rumah Sakit Umum Pusat Cipto Mangunkusumo (RSCM) Jakarta sejak awal tahun 2009 hingga saat ini menangani 61 kasus syok septik pada anak, dan 28 kasus $(45,9 \%)$ di antaranya berakhir dengan kematian. ${ }^{3}$

Sejak abad ke-19 para peneliti telah melakukan eksplorasi terhadap mekanisme biologis syok septik untuk menentukan pilihan intervensi. Kortikosteroid merupakan salah satu pilihan terapi yang banyak 
diteliti dan diperdebatkan karena interaksinya dengan respons imun dan efek antiinflamasi. ${ }^{4}$ Pada keadaan normal kortisol berespons terhadap inflamasi melalui dampaknya terhadap sel darah putih, sitokin, dan produksi nitrit oksida. Namun, sitokin dapat menekan respons kortisol terhadap hormon adrenokortikotropin, menyebabkan penurunan aktivitas kelenjar adrenal, sehingga jaringan tubuh dapat menjadi resisten terhadap kortikosteroid. ${ }^{5}$ Prevalens insufisiensi adrenal pada syok septik sangat bervariasi dalam penelitian-penelitian sebelumnya, yakni antara $15 \%$ hingga $61 \% .{ }^{6}$ Karena alasan inilah kortikosteroid dipikirkan dapat bermanfaat pada syok septik.

\section{Kasus}

Seorang anak lelaki berusia 15 bulan dibawa ke IGD RSUP Cipto Mangunkusumo tanggal 16 Agustus 2009 dengan keluhan muntah sejak lima hari sebelum datang ke rumah sakit. Keluhan disertai demam tinggi dan asupan makanan yang mulai berkurang. Pasien hanya diberi obat penurun panas di rumah dan tidak dibawa berobat. Sejak tiga hari sebelum datang ke rumah sakit pasien buang air besar mencret $3 \mathrm{x} /$ hari, jumlah 50-100 ml setiap mencret, konsistensi bubur. Saat muntah bertambah banyak dan tidak ada asupan yang masuk, orangtua membawa pasien ke rumah sakit.

Saat tiba di IGD anak sadar namun tampak lemah dan rewel. Laju nadi $126 \mathrm{kali} / \mathrm{menit}$, terat ur, isi cukup, laju nafas $32 \mathrm{kali} / \mathrm{menit}$, teratur, kedalaman cukup, suhu $36,7^{\circ} \mathrm{C}$ (aksila). Berat badan 6,3 kg (<P3 CDCNCHS 2000), tinggi badan $69 \mathrm{~cm}(<\mathrm{P} 3$ CDC-NCHS 2000), dengan indeks antropometri didapatkan $\mathrm{BB} /$ $\mathrm{U}=56,3 \%$, TB/U=87,34\%, BB/TB=73,25\%. Pada pemeriksaan fisis didapatkan mata cekung, terdapat air mata mengalir, mukosa kering, turgor kulit buruk, terdapat wasting dan baggy pants, dan pemeriksaan lainnya dalam batas normal.

Pasien dirawat dengan diagnosis kerja awal gizi buruk tipe marasmik dan diare akut dehidrasi ringansedang, mendapat terapi antibiotik sefotaksim dosis biasa dan tata laksana dehidrasi pada gizi buruk berupa diet F75, resomal, serta vitamin A dan asam folat. Setelah satu hari dirawat, diare pasien semakin berat, frekuensi lebih dari 10 kali per hari dengan volume 100-150 $\mathrm{ml}$ setiap mencret, kesadaran tampak menurun, nafas cepat, dan pasien akhirnya dipindahkan ke ICU Anak Departemen IKA RSCM karena terjadi syok hipovolemik.

Selama perawatan di ICU Anak, klinis pasien menunjukkan proses sepsis berat yang ditandai dengan penurunan kesadaran, takikardia, instabilitas suhu, gagal nafas, perdarahan saluran cerna, epistaksis, purpura pada kulit sekitar abdomen dan bahu, dan syok berulang. Pada pemeriksaan laboratorium didapatkan pansitopenia dengan kadar hemoglobin $8 \mathrm{~g} / \mathrm{dL}$, hematokrit 27,6 vol\%, hitung leukosit $2800 / \mu \mathrm{L}$, hitung trombosit $24.000 / \mu \mathrm{L}$. Terdapat hipoglikemia berulang, pemanjangan prothrombin time dan activated partial thromboplastin time (PT/ aPTT). Kadar prokalsitonin mencapai 3,43 ng/mL (nilai $>2 \mathrm{ng} / \mathrm{mL}$ menandakan adanya sepsis berat). Pada biakan darah tumbuh kuman Proteus mirabilis, pada biakan urin Acinetobacter sp. dan Candida albicans yang keduanya berjumlah $>100.000$ koloni $\mathrm{kuman} / \mathrm{mL}$.

Terapi yang diberikan di ICU Anak adalah antibiotik meropenem dosis sepsis sesuai hasil biakan dan uji sensitivitas darah dan urin, antijamur sistemik, transfusi darah sesuai indikasi, serta terapi inotropik serta vasopresor. Meskipun telah diberikan terapi yang adekuat, klinis pasien tidak membaik dan hemodinamik tidak stabil meski dalam dukungan inotropik dopamin, dobutamin, dan norepinefrin yang dieskalasi sesuai klinis hingga mencapai dosis maksimal. Pasien kemudian diputuskan untuk mendapatkan steroid, namun keadaan umum pasien memburuk sebelum steroid sempat diberikan. Saat dilakukan resusitasi, tidak ada respons klinis dengan pemberian adrenalin serta sulfas atropin dan akhirnya pasien meninggal dunia.

\section{Masalah klinis}

Angka mortalitas pada sepsis masih tinggi, meskipun telah mendapatkan terapi antibiotik dan tata laksana suportif yang adekuat. Steroid merupakan salah satu pilihan terapi pada sepsis yang masih merupakan kontroversi sejak empat puluh tahun yang lalu. Berdasarkan hal tersebut, diajukan pertanyaan klinis sebagai berikut: "Apakah pemberian steroid akan memberikan respon terapi yang lebih baik dan meningkatkan kesintasan pada pasien sepsis dibandingkan terapi konvensional?” 


\section{Metode penelusuran}

Untuk menjawab masalah klinis, dilakukan penelusuran kepustakaan secara online menggunakan instrumen pencari Pubmed, Highwire, Cochrane Library, Google, dan Yahoo! Kata kunci yang digunakan adalah steroids, corticosteroids, sepsis, dan septic shock, dengan menggunakan batasan (limit): studi yang dilakukan pada manusia, publikasi bahasa Inggris, kata kunci terdapat pada judul atau abstrak, serta jenis publikasi berupa uji klinis, uji klinis terandomisasi, meta-analisis, dan review.

Dengan metode tersebut, pada awalnya didapatkan 576 artikel yang memenuhi kriteria. Penelusuran lebih lanjut dilakukan secara manual pada daftar pustaka yang relevan. Setelah penelusuran judul dan abstrak artikel-artikel tersebut, didapatkan 16 artikel yang relevan dengan masalah, terdiri dari 4 artikel telaah sistematik, 9 artikel uji klinis acak terkontrol, 1 artikel kohort, dan 2 artikel review. Levels of evidence ditentukan berdasarkan klasifikasi yang dikeluarkan oleh Oxford Centre for Evidence-based Medicine Levels of Evidence ${ }^{7}$ atau Methodologic Quality Form yang disusun oleh Cronin $\mathrm{L} \mathrm{dkk}^{8}$ (skor maksimal 14,5).

\section{Hasil penelusuran}

Empat puluh tahun yang lalu, steroid dosis tinggi mulai digunakan sebagai bagian tata laksana sepsis atas dasar keyakinan bahwa sepsis merupakan suatu respons inflamasi, sehingga efek anti-inflamasi yang dimiliki steroid dianggap dapat bermanfaat. Schumer $\mathrm{W}^{9} \mathrm{di}$ tahun 1976 pertama kali mempublikasikan bahwa terapi deksametason $(3 \mathrm{mg} / \mathrm{kg})$ atau metilprednisolon $(30 \mathrm{mg} / \mathrm{kg})$ intravena dalam larutan salin normal menyebabkan mortalitas yang lebih rendah $(10,4 \%$ dan $9,3 \%$ ) dibandingkan dengan larutan salin normal saja $(38,4 \%)$ pada 172 pasien dengan syok septik (level of evidence: 2c, skor Cronin 6.0). Schumer pada saat yang bersamaan juga mempublikasikan studi retrospektif pada 328 pasien, dengan mortalitas $42,5 \%$ pada pasien dengan terapi larutan salin normal dibandingkan $14 \%$ dengan terapi tambahan steroid. Pada penelitian ini tidak disebutkan definisi terapi antibiotik yang adekuat dan tata laksana suportif.

Dua uji klinik acak terkontrol tersamar ganda berskala besar yang dilakukan beberapa tahun kemudian pada tahun 1987 mendapatkan hasil yang bertentangan. Bone $\mathrm{RC} \mathrm{dkk}^{10}$ memberikan terapi metilprednisolon $30 \mathrm{mg} / \mathrm{kg}$ versus plasebo sampai empat dosis pada pasien dengan sepsis berat atau syok septik, dalam waktu dua jam setelah diagnosis (level of evidence: 1b, skor Cronin 11). Pada penelitian lain, VA Systemic Sepsis Cooperative Study Group ${ }^{11}$ menggunakan metilprednisolon $30 \mathrm{mg} / \mathrm{kg}$ bolus yang diikuti dengan infus $5 \mathrm{mg} / \mathrm{kg}$ selama 9 jam versus plasebo pada pasien sepsis (level of evidence: 1b, skor Cronin 14). Kedua penelitian ini tidak dapat membuktikan bahwa mortalitas akibat sepsis pada kelompok glukokortikoid lebih rendah dibandingkan plasebo. Penelitian tersebut menemukan mortalitas akibat infeksi sekunder yang lebih tinggi pada kelompok yang diberi steroid setelah dua minggu perawatan.

Dua buah analisis meta yang dipublikasikan tahun 1995 menyimpulkan bahwa pemberian steroid pada sepsis tidak efektif ${ }^{12}$ dan cenderung membahayakan. ${ }^{8}$ Meta analisis Lefering R dan Neugebauer EA ${ }^{12}$ tahun 1995 pada 49 publikasi yang meneliti efek kortikosteroid pada pasien sepsis dan syok septik mendapatkan hanya satu dari sepuluh studi yang memperlihatkan efek positif steroid secara bermakna (level of evidence: 1a). Tidak ditemukan perbedaan antar jenis dan dosis kortikosteroid yang digunakan. Pasien dengan infeksi Gram negatif menunjukkan keluaran yang lebih baik dibandingkan Gram positif (-5,6\% versus 1,8\%). Tidak ditemukan efek kortikosteroid yang menguntungkan pada pasien dengan syok septik, namun terdapat efek positif pada pasien dengan septikemia Gram negatif. Cronin L $\mathrm{dkk}^{8}$ juga melakukan metaanalisis pada 9 uji klinik acak terkontrol dan mendapatkan bahwa kortikosteroid meningkatkan mortalitas pasien sepsis dan mortalitas akibat infeksi sekunder (level of evidence: 1a, skor Cronin 14). Sama halnya dengan metaanalisis Lefering R dan Neugebauer EA, Cronin L menyimpulkan bahwa pemberian steroid pada sepsis tidak bermanfaat dan bahkan berbahaya.

Pada akhir 1990-an, beberapa penelitian yang dipublikasikan menyatakan adanya peran steroid dengan dosis yang jauh lebih rendah, yang disebut steroid dosis stres (stress-dose), untuk mengurangi kebutuhan vasopresor pada pasien dengan syok septik. ${ }^{13-15}$ Data klinis mengenai tekanan arteri rata-rata (MAP) setelah pemberian norepinefrin menunjukkan respons yang lebih baik terhadap norepinefrin pada pasien dengan fungsi adrenal normal dibandingkan dengan pasien yang mengalami gangguan fungsi adrenal. ${ }^{13}$ Bila kortikosteroid dosis rendah diberikan 
pada pasien dengan gangguan fungsi adrenal, maka respons ini akan meningkat (level of evidence: $2 \mathrm{~b}$, skor Cronin 14).

Sejak tahun 1997, para peneliti mulai menggunakan kortikosteroid dengan dosis yang lebih rendah dan durasi yang lebih panjang. Uji klinis prospektif acak tersamar ganda yang dilakukan oleh Bollaert PE $\mathrm{dkk}^{14}$ meneliti 41 pasien yang memerlukan katekolamin lebih dari 48 jam dan telah berada dalam keadaan syok selama 5-6 hari (level of evidence: 1b, skor Cronin 14). Pada saat itu kuman penyebab telah dapat diidentifikasi pada pasien dan kemungkinan besar telah mendapat antibiotik yang sesuai, sehingga meminimalkan komplikasi kortikosteroid. Pasien diberikan $100 \mathrm{mg}$ hidrokortison intravena tiga kali sehari selama 5 hari. Terapi dihentikan bila syok tidak membaik. Apabila syok perbaikan, maka terapi dilanjutkan dengan setengah dosis selama tiga hari dan seperempat dosis selama tiga hari berikutnya, kemudian dihentikan. Terdapat perbaikan syok pada hari ke-7, dan angka mortalitas pada hari ke-28 menampakkan kecenderungan yang bermakna (63\% versus $32 \%)$.

Briegel J dkk ${ }^{15}$ melakukan suatu uji klinik prospektif acak tersamar ganda pada pasien syok septik yang sedang dalam terapi vasopresor dan telah mengalami syok sedikitnya selama tiga hari (level of evidence: $1 \mathrm{~b}$, skor Cronin 14). Selama dalam terapi vasopresor, pasien diberikan bolus $100 \mathrm{mg}$ hidrokortison atau plasebo, diikuti infus hidrokortison $0,18 \mathrm{mg} / \mathrm{kg} / \mathrm{jam}$ atau plasebo. Pada kelompok steroid, waktu rata-rata hingga syok teratasi lebih singkat dan insidens disfungsi organ lebih rendah dibandingkan dengan kelompok kontrol.

Hasil penelitian tersebut mendorong Annane $\mathrm{D} \mathrm{dkk}^{17}$ melakukan penelitian pada pasien dengan insufisiensi adrenal relatif, yaitu yang tidak menunjukkan respons terhadap uji kortikotropin, yang diberi terapi hidrokortison (50 mg intravena tiap 6 jam) dan fludrokortison $(50 \mu \mathrm{g}$ oral/hari) dosis rendah selama 7 hari. Tingkat mortalitas didapatkan lebih rendah pada pasien syok septik dengan insufisiensi adrenal yang mendapat terapi tersebut, tanpa meningkatkan efek samping (level of evidence: $1 \mathrm{~b}$, skor Cronin 14,5). ${ }^{16}$ Analisis meta Cochrane database pada enam uji klinik yang menggunakan kortikosteroid jangka pendek dosis tinggi tidak memperlihatkan penurunan mortalitas pada 28 hari (level of evidence: 1a, skor Cronin 14,5). ${ }^{17}$ Meskipun tidak terdapat hasil yang bermakna secara statistik pada mortalitas secara keseluruhan pada 28 hari, hasil penelitian ini membuat steroid direkomendasikan untuk terapi pasien dengan syok septik. ${ }^{18}$ Maka disimpulkan, semua pasien syok septik perlu diberikan kortikosteroid dosis rendah dalam waktu 24 jam setelah diagnosis. ${ }^{18}$

Namun demikian masih terdapat keraguan, sehingga dilakukan suatu penelitian berskala besar, internasional, multisenter untuk memastikan hasil penelitian sebelumnya. Penelitian Corticus (Corticosteroid Therapy of Septic Shock) yang mengikutsertakan hampir 500 subjek memperlihatkan bahwa hidrokortison tidak meningkatkan kesintasan maupun mengatasi syok pada pasien syok septik, baik secara keseluruhan maupun pada pasien yang tidak menunjukkan respons terhadap uji kortikotropin (level of evidence: $1 \mathrm{~b}$, skor Cronin 12,5). ${ }^{19}$ Hasil dari penelitian Corticus tidak banyak memberikan kontribusi, dan pada editorial jurnal yang menyertainya, Finfer $S^{20}$ menyatakan perlunya penelitian lebih lanjut untuk mengeksplorasi efek steroid pada syok septik dalam populasi yang lebih luas.

Review oleh Richardson L dan Hunter $S^{21}$ pada tahun 2008 juga menemukan bahwa steroid tidak memiliki efek pada mortalitas, namun memperpendek durasi syok, sehingga fungsinya terbatas pada syok septik. Steroid terbukti memiliki efek imunologi dan hemodinamik yang menguntungkan bagi pasien sepsis berat (level of evidence: $2 \mathrm{a}$ ).

Kebijakan awal mengenai steroid pada sepsis dalam Surviving Sepsis Guidelines yang pertama kali dipublikasikan pada tahun 2004 adalah mencantumkan pemberian steroid dosis rendah dalam prosedur operasional standar (standard operational procedure, SOP) ${ }^{18}$ Kortikosteroid intravena (hidrokortison 200 $300 \mathrm{mg} /$ hari, dibagi 2-3 dosis dan diberikan selama 7 hari) direkomendasikan pada pasien syok septik yang memerlukan terapi vasopresor meskipun volume cairan adekuat. Uji stimulasi ACTH $250 \mu \mathrm{g}$ tidak wajib dilakukan, dan pemberian steroid tidak boleh ditunda hingga ada hasil uji stimulasi. Meskipun steroid kurang membantu pada pasien tanpa insufisiensi adrenal, namun tidak membahayakan jika diberikan. Steroid dosis rendah memperbaiki kesintasan pada syok septik yang refrakter katekolamin.

Dellinger RP $\mathrm{dkk}^{22}$ mengeluarkan Guideline terbaru pada tahun 2008 yang menyarankan untuk mempertimbangkan pemberian hidrokortison pada pasien dengan syok septik yang kurang responsif terhadap cairan dan obat vasopresor (level of evidence: 
2C). Uji stimulasi ACTH tidak direkomendasikan pada pasien yang harus mendapat steroid (level of evidence: 2B). Steroid tidak boleh digunakan untuk terapi sepsis tanpa syok kecuali bila didukung oleh riwayat gangguan endokrin atau kortikosteroid (level of evidence: 1D). (Gambar 1)

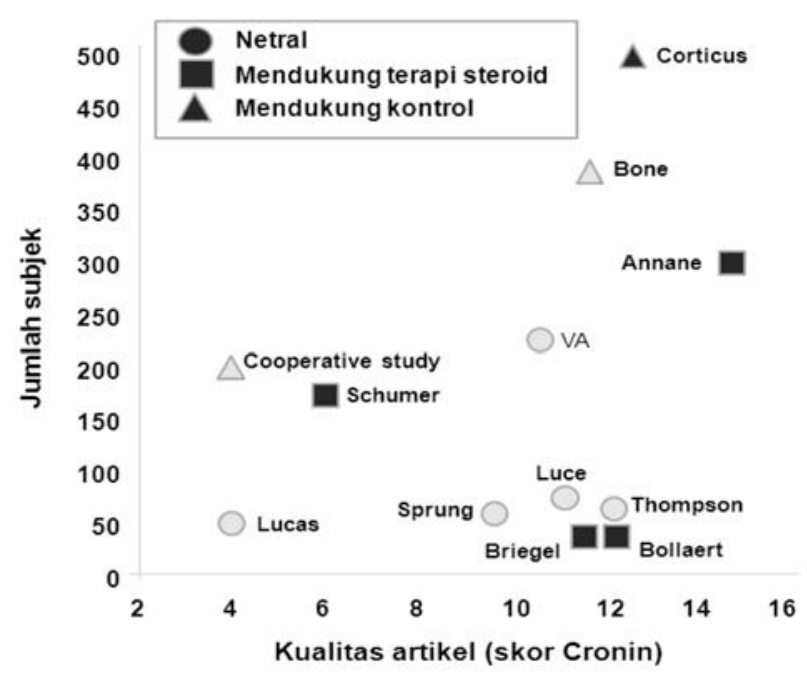

Gambar 1. Ilustrasi kualitas artikel hasil penelusuran dengan skor Cronin 17

\section{Pembahasan}

Sepsis adalah suatu respons inflamasi sistemik akibat infeksi. ${ }^{23}$ Syok septik merupakan respons inflamasi yang lebih berat, yang ditandai dengan adanya hipotensi persisten meskipun dengan resusitasi cairan yang adekuat, atau perlunya obat-obat vasoaktif untuk mendapatkan tekanan darah yang adekuat, disertai bukti adanya gangguan perfusi, seperti gangguan kesadaran, asidosis laktat, atau berkurangnya produksi urin.

Kortikosteroid digunakan sebagai obat utama dalam beberapa penyakit inflamasi untuk menekan proses proinflamasi yang berlebihan, seperti pada asma, penyakit kolagen, vaskulitis, dan penyakit autoimun. Efek anti inflamasi inilah yang menyebabkan glukokortikoid pada awalnya dipikirkan dapat memperbaiki perjalanan penyakit dan menurunkan mortalitas pada syok septik. Dampak anti inflamasi steroid tertera pada Tabel 1 .

Selain efek antiinflamasi, steroid juga memiliki beberapa fungsi lain pada syok septik, yaitu menghambat enzim nitrit oksida sintase yang memiliki efek vasodilatasi, sehingga hemodinamik tetap terjaga stabil. Efek lain kortikosteroid yang lebih penting adalah meningkatkan respons pembuluh darah terhadap pemberian katekolamin eksogen. Penelitian Annane D $\mathrm{dkk}^{13}$ membuktikan bahwa pasien syok septik dengan produksi kelenjar adrenal yang normal memberikan respons yang lebih baik terhadap vasopresor dibandingkan pasien dengan insufisiensi adrenal relatif.

Penggunaan kortikosteroid sebagai salah satu terapi sepsis telah banyak menjadi topik perdebatan selama lebih dari empatpuluh tahun. Meskipun banyak data

Tabel 1. Efek anti inflamasi steroid

\begin{tabular}{llll}
\hline Efek melalui lipokortin & Efek pada interleukin & Efek pada netrofil & Efek lain \\
\hline $\begin{array}{l}\text { Membantu sel PMN* } \\
\text { berespon terhadap stimulus }\end{array}$ & Menghambat sintesis IL-1 & Stabilisasi lisosom netrofil & $\begin{array}{l}\text { Mencegah aktivasi kaskade } \\
\text { komplemen }\end{array}$ \\
$\begin{array}{l}\text { Menghambat fosfolipase A2 } \\
\text { dan mencegah pembentukan } \\
\text { prostaglandin }\end{array}$ & $\begin{array}{l}\text { Menghambat IL-6 } \\
\text { MRNA IL-3 }\end{array}$ & $\begin{array}{l}\text { Menghambat pelepasan } \\
\text { enzim lisosom } \\
\text { menghambat kemotaksis }\end{array}$ & $\begin{array}{l}\text { Menghambat nitrit oksida } \\
\text { sintase eksogen }\end{array}$ \\
$\begin{array}{l}\text { Perubahan pada Ca2+ terikat } \\
\text { membran }\end{array}$ & $\begin{array}{l}\text { Menurunkan kinerja sitokin } \\
\text { dan faktor pertumbuhan }\end{array}$ & $\begin{array}{l}\text { Mengurangi respon } \\
\text { inflamasi }\end{array}$ & $\begin{array}{l}\text { Mengurangi platelet- } \\
\text { activating factor pada } \\
\text { pelepasan endotoksin }\end{array}$ \\
$\begin{array}{l}\text { Menurunkan kemampuan } \\
\text { netrofil dalam melepaskan } \\
\text { metabolit oksigen aktif }\end{array}$ & $\begin{array}{l}\text { Mencegah pelepasan TNF } \\
\text { dan IL-1 dari sel mononu- } \\
\text { klear }\end{array}$ & $\begin{array}{l}\text { Mencegah hiperagregasi dan } \\
\text { adhesi leukosit yang dipicu } \\
\text { endotoksin }\end{array}$ & \\
\hline
\end{tabular}

*sel PMN= sel polimononuklear

Sari Pediatrī, Vol. 11, No. 6, April 2010 
penelitian preklinik yang mendukung keuntungan penggunaan steroid dalam meningkatkan kesintasan, namun data penelitian in vivo pada pasien sepsis kurang mendukung hal ini. Banyak laporan yang menunjukkan potensi bahaya pemberian kortikosteroid dosis tinggi pada awal perjalanan penyakit, karena itu penggunaan steroid pada sepsis kemudian menjadi tidak populer.

Di sisi lain, mulai diketahui bahwa pada sepsis, terutama sepsis berat dan syok septik terdapat insufisiensi adrenal relatif. Pada tahun 2000 Annane $\mathrm{D} \mathrm{dkk}^{5}$ mendapatkan bahwa insufisiensi adrenal relatif, yang didefinisikan sebagai peningkatan kadar kortisol darah kurang dari $9 \mu \mathrm{g} / \mathrm{dL} 60$ menit setelah pemberian ACTH $250 \mu$ g, terjadi pada 54\% dari 189 pasien syok septik yang diteliti.

Penelitian Knighton JD $\mathrm{dkk}^{24}$ membuktikan bahwa kesintasan pada penyakit berat akan menurun apabila terdapat insufisiensi adrenal. Pasien- sepsis yang tidak dapat bertahan hidup telah terbukti menunjukkan respons inflamasi yang seringkali disertai oleh peningkatan kadar kortisol dan kortikotropin dalam darah. Kadar kortisol tinggi di dalam darah menunjukkan resistensi terhadap glukokortikoid. Keadaan yang bertentangan antara peningkatan kadar kortisol dan penurunan efek kortisol menimbulkan kecurigaan penurunan afinitas pengikatan kortisol pada reseptor glukokortikoid. Selain itu, terjadi pula desensitisasi reseptor adrenergik, karena jumlah reseptor alfa maupun beta adrenergik berkurang. Hal ini dapat disebabkan oleh keadaan sepsis itu sendiri atau akibat penggunaan vasopresor dalam waktu lama. Untuk itu dipikirkan perlunya pemberian tambahan kortikosteroid dalam dosis fisiologis untuk mengatasi gangguan ini. Kortikosteroid diduga membantu dalam resensitisasi reseptor-reseptor tersebut sehingga dapat menstabilkan hemodinamik, mengurangi kebutuhan katekolamin, memperbaiki keadaan syok dan mungkin memperbaiki kegagalan sistem organ. Semua dampak positif kortikosteroid dapat menurunkan mortalitas.

Pemberian dosis fisiologis membantu memperbaiki insufisiensi adrenal relatif tanpa menyebabkan imunosupresi. Insufisiensi adrenal relatif ini tidak selalu bermanifestasi dalam bentuk penurunan respons kortisol terhadap pemberian kortikotropin. Beberapa penelitian menunjukkan tidak ada hubungan antara respons kortisol terhadap pemberian kortikotropin, dan terdapat efek menguntungkan dari pemberian kortikosteroid baik dari segi klinis maupun hemodinamik.
Sebagian ahli tidak mendukung pemberian kortikosteroid secara empiris pada sepsis dengan beberapa alasan. Pertama, respons terhadap kortikotropin ditemukan dengan tingkat yang bervariasi pada berbagai penelitian, dan setengah dari seluruh pasien memberikan respons normal sehingga membuktikan pentingnya pemeriksaan kortikotropin terlebih dahulu sebelum pemberian kortikosteroid. Kedua, efek samping akibat kortikosteroid cukup sering terjadi, seperti infeksi sekunder, perdarahan saluran cerna, dan peningkatan kadar gula darah, yang akhirnya ikut meningkatkan mortalitas. Ketiga, sebagian penelitian yang mendukung terapi steroid empiris pada pasien sepsis memiliki kekurangan, misalnya dalam hal pemilihan subjek. Ada kemungkinan bahwa sebagian subjek yang diikutsertakan dalam penelitian sebenarnya mengalami insufisiensi adrenal primer atau sekunder. Gambaran klinis krisis adrenal terkadang sulit dibedakan dengan syok septik. Bila pasien dengan insufisiensi adrenal sejati masuk ke dalam kelompok plasebo dan tidak mendapat steroid akan memberikan kesintasan yang buruk, sehingga hasilnya seakan-akan mendukung kelompok steroid. Keempat, preparat cosyntropin dan synacthen (analog kortikotropin sintetik/alpha-kortikotropin) sulit dicari, bahkan di Amerika Serikat sekalipun.

Pada kasus kami, pasien mengalami sepsis berat yang berlanjut menjadi syok septik. Diagnosis pada pasien kami ditegakkan atas dasar ditemukan demam, leukopenia dan takikardia (tiga dari empat kondisi systemic inflammatory response syndrome = SIRS), disertai dengan biakan darah positif dan gangguan hemodinamik yang memerlukan pemberian vasopresor dan inotropik.

Selama perawatan, pasien telah mendapat terapi antibiotik sefotaksim selama lima hari, dilanjutkan meropenem selama lima hari, dan pemberian anti jamur, namun tidak menampakkan perbaikan yang berarti. Hal tersebut dapat disebabkan oleh faktor kuman maupun pejamu, dan pada pasien kami terdapat faktor risiko kerentanan pejamu karena status gizi buruk. Defisiensi nutrien, baik kualitatif maupun kuantitatif, dapat mengganggu respons imun humoral maupun selular, dan merupakan penyebab kedua terbanyak imunodefisiensi sekunder setelah acquired immunodeficiency syndrome (AIDS) ${ }^{25}$

Inotropik dan vasopresor yang diberikan yaitu dopamin, dobutamin, dan norepinefrin telah mencapai dosis maksimal, namun belum tampak perbaikan pada 
pasien dan hemodinamik tetap tidak stabil. Pemberian steroid direncanakan karena respons terhadap antibiotik, inotropik, dan vasopresor kurang adekuat. Sebelum kortikosteroid sempat diberikan, terjadi perburukan pada pasien yang tidak dapat diatasi, dan pasien meninggal dunia. Apabila diberikan lebih awal dalam perjalanan penyakit, ada kemungkinan pasien akan memberikan respons yang lebih baik terhadap vasopresor sehingga meningkatkan kemungkinan kesintasan. Sedangkan uji fungsi adrenal tidak dilakukan pada pasien kami.

Surviving Sepsis Campaign merekomendasikan pemberian kortikosteroid stress dose tanpa pemeriksaan fungsi adrenal terlebih dahulu. ${ }^{22}$ The American College of Critical Care Medicine Task Force sebaliknya memberikan rekomendasi agar kortikosteroid stress dose hanya digunakan pada syok septik yang refrakter atau pada pasien dengan insufisiensi adrenal, yakni yang tidak memberikan respons terhadap stimulasi kortikotropin. ${ }^{26}$

Penelitian-penelitian mengenai penggunaan steroid pada sepsis memberikan hasil yang sangat bervariasi dan beberapa bahkan sangat bertentangan. Pada era evidence-based medicine seperti sekarang ini, uji klinik yang dirancang dengan baik dan mempunyai tujuan yang sesuai sangat diperlukan, sehingga dapat memberikan data yang dapat dipercaya dan dapat menjadi dasar bagi penyusunan guidelines serta rekomendasi tata laksana pasien dengan syok septik.

\section{Kesimpulan}

Kortikosteroid tidak dianjurkan pada pasien sepsis dengan hemodinamik stabil. Kortikosteroid dosis tinggi jangka pendek tidak bermanfaat dan justru dapat membahayakan pasien dengan sepsis berat dan syok septik. Data efektivitas dan keamanan obat yang tersedia saat ini mendukung pemberian kortikosteroid dosis rendah jangka panjang pada semua pasien dengan syok septik yang dependen vasopresor, tanpa mempertimbangkan hasil uji stimulasi ACTH. Keputusan untuk memberikan steroid pada syok septik harus dilakukan berdasarkan keputusan klinis, dan bukan semata berdasarkan hasil laboratorium maupun protokol. Terapi kortikosteroid pada pasien dengan syok septik persisten membantu memperbaiki keadaan syok dan lebih cepat memulihkan gangguan hemodinamik, sehingga menurunkan mortalitas.
Masih diperlukan penelitian lebih lanjut untuk memastikan rekomendasi ini dan untuk menentukan jenis steroid, dosis, waktu, dan lama terapi.

\section{Daftar Pustaka}

1. Angus D, Linde-Zwirble WT, Lidicker J, Clermont G, Carcillo J, Pinsky MR. Epidemiology of severe sepsis in the United States: analysis of incidence, outcome, and associated costs of care. Crit Care Med 2001;29:1303-10.

2. Annane D, Aegerter P, Jars-Guincestre MC, Guidet B. Current epidemiology of septic shock: the CUB-Réa Network. Am J Resp Crit Care Med 2003;168:16572.

3. Data Rekam Medis Departemen Ilmu Kesehatan Anak Fakultas Kedokteran Universitas Indonesia - Rumah Sakit Umum Pusat Nasional Cipto Mangunkusumo. Diakses tanggal 6 November 2009.

4. Annane D, Cavaillon JM. Corticosteroids in sepsis: from bench to bedside? Shock 2003;20:197-207.

5. Annane D, Sébille V, Troché G, Raphael JC, Gajdos P, Bellissant E. A 3-level prognostic classification in septic shock based on cortisol levels and cortisol response to corticotrophin. JAMA 2000;283:1038-45.

6. Pizzaro CF, Troster EJ. Adrenal function in sepsis and septic shock. J Pediatr (Rio J). 2007;83(5 Suppl):S15562.

7. Oxford Centre of Evidence-based Medicine. Oxford Centre for evidence-based medicine levels of evidence (March 2009). Diunduh dari: http://www.cebm.net/index. asox?o=1025. Diakses pada tanggal 1 Oktober 2009.

8. Cronin L, Cook DJ, Carlet J, Heyland DK, King D, Lansang MA, dkk. Corticosteroid treatment for sepsis: a critical appraisal and meta-analysis of the literature. Crit Care Med 1995,23:1430-9.

9. Schumer W. Steroids in the treatment of clinical septic shock. Ann Surg 1976;184:333-41.

10. Bone RC, Fisher CJJ, Clemmer TP, Slotman GJ, Metz CA, Balk RA: A controlled clinical trial of high-dose methylprednisolone in the treatment of severe sepsis and septic shock. N Engl J Med 1987;317:653-8.

11. Veterans Administration Systemic Sepsis Cooperative Study Group: Effect of high-dose glucocorticoid therapy on mortality in patients with clinical signs of systemic sepsis. N Engl J Med 1987;317:659-65.

12. Lefering R, Neugebauer EA. Steroid controversy in sepsis and septic shock: a meta-analysis. Crit Care Med 1995;23:1294-303. 
13. Annane D, Bellissant E, Sebille V, Lesieur O, Mathieu B, Raphael JC, dkk. Impaired pressor sensitivity to noradrenaline in septic shock patients with and without impaired adrenal function reserve. Br J Clin Pharmacol 1998;46:589-97.

14. Bollaert PE, Charpentier C, Levy B, Debouverie M, Audibert G, Larcan A. Reversal of late septic shock with supraphysiologic doses of hydrocortisone. Crit Care Med 1998;26:645-50.

15. Briegel J, Forst H, Haller M, Schelling G, Kilger E, Kuprat G, dkk. Stress doses of hydrocortisone reverse hyperdynamic septic shock: a prospective, randomized, double-blind, single-center study. Crit Care Med 1999;27:723-32.

16. Annane D, Sebille V, Charpentier C, Bollaert PE, Francois B, Korach JM, dkk. Effect of treatment with low doses of hydrocortisone and fludrocortisone on mortality in patients with septic shock. JAMA 2002;288:86271.

17. Annane D, Bellissant E, Bollaert PE, Briegel J, Keh D, Kupfer Y. Corticosteroids for treating severe sepsis and septic shock. Cochrane Database Syst Rev 2004; 1:CD002243.

18. Dellinger RP, Carlet JM, Masur H, Gerlach H, Calandra T, Cohen J, dkk. Surviving sepsis campaign guidelines for management of severe sepsis and septic shock. Crit Care Med. 2004;32:858-73.

19. Sprung CL, Annane D, Keh D, Moreno R, Singer M, Freivogel K, dkk. Hydrocortisone therapy for patients with septic shock. N Engl J Med 2008;358:111-24.

20. Finfer S. Corticosteroids in septic shock. N Engl J Med 2008;358:188-90.

21. Richardson L, Hunter S. Is steroid therapy ever benefit to patients in the intensive care unit going into septic shock? Interact CardioVasc Thorac Surg. 2008;7:898-905.

22. Dellinger RP, Levy MM, Carlet JM, Bion J, Parker MM, Jaeschke M, dkk. Surviving sepsis campaign: International guidelines for management of severe sepsis and septic shock: 2008. Crit Care Med 2008;36:296327.

23. Bone RC, Balk RA, Cerra FB. Definitions for sepsis and organ failure and guidelines for the use of innovative therapies in sepsis: the ACCP/SCCM Consensus Conference Committee, American College of Chest Physicians/ Society of Critical Care Medicine. Chest 1992;101:1644-55.

24. Knighton JD, Woodock TE, Hough M. Adrenal failure in the critically ill. Br J Anaesth 1999;82:152-3.

25. Cantani A. Malnutrition and the immune system. Chapter 21. Dalam: Cantani A. Pediatric Allergy, Asthma and Immunology. Berlin: Springer, 2008. h 1243-64.

26. Marik PE, Pastores SM, Annane D, Meduri GU, Sprung CL, Arlt W, dkk. Recommendations for the diagnosis and management of corticosteroid insufficiency in critically ill adult patients: Consensus statements from an international task force by the American College of Critical Care Medicine. Crit Care Med 2008;36:193749. 